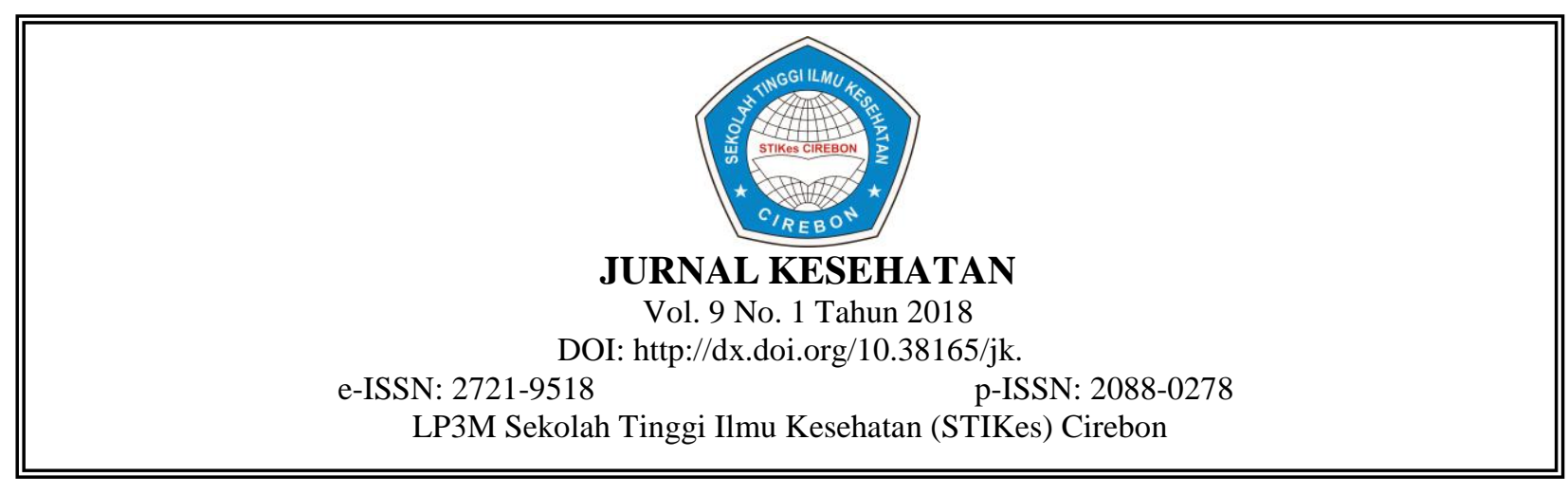

\title{
TINGKAT KEPUASAN MAHASISWA TINGKAT II TERHADAP PELAYANAN BAGIAN KEUANGAN STIKes
}

\author{
Indra Karana Napitupulu* \\ Sekolah Tinggi Ilmu Kesehatan Dharma Husada Bandung \\ indrakelana2009@gmail.com
}

\begin{abstract}
Abstrak
Kepuasan adalah perasaan senang ataupun kecewa seseorang yang berasal dari perbandingan antara kesannya terhadap kinerja (atau hasil) suatu produk dan harapan-harapannya. Penelitian ini bertujuan untuk mengetahui secara umum tingkat kepuasan mahasiswa terhadap pelayanan bagian keuangan yang ada di lingkungan STIKes Dharma Husada Bandung. Total responden adalah 102 mahasiswa dari perwakilan seluruh program studi. Instrumen kuisioner terdiri dari 20 pernyataan. Dari semua kuesioner yang telah disebarkan, kuesioner yang masuk/kembali pada tanggal yang telah ditentukan untuk pengolahan data sebanyak 102 kuesioner. Analisis data dilakukan secara univariat. Hasil penelitian tentang tingkat kepuasan pelayanan bagian keuangan di STIKes Dharma Husada Bandung, menunjukkan nilai kepuasan secara umum sebagai berikut : penilaian untuk kuisioner harapan terhadap sampel responden yang ada memberikan hasil skor rata-rata $>5,00$ dengan kategori kalsifikasi adalah sangat Pentingsebesar $60(58,8 \%)$ responden artinya adalah mahasiswa menilai pernyataan kuisioner yang diberikan sangat penting untuk diaplikasikan. Sedangkan penilaian untuk kuisioner kenyataan terhadap respon responden memberikan hasil skor rata - rata $>4,00-<4,99$ dengan kategori klasifikasi adalah puas sebesar $60(58,8 \%)$ responden artinya mahasiswa merasa puas dengan pelayanan bagian keuangan STIKes Dharma Husada Bandung.
\end{abstract}

Kata Kunci: Tingkat Kepuasan, Pelayanan

\begin{abstract}
Satisfaction is the feeling of pleasure or disappointment of someone who derives from the comparison between his impressions of the performance (or outcome) of a product and its expectations. The studi aims to is to determine the general level of student satisfaction with the service of the financial department in the STIKes Dharma Husada Bandung. The total respondents were 102 students from representatives of all study programs. The questionnaire instrument consists of 20 statements. Of all the questionnaires that have been distributed, the questionnaire that entered/returned on a predetermined date for processing 102 data questionnaires. Data analysis is done univariat The results of research on the level of satisfaction of financial services in STIKes Dharma Husada Bandung, showed the value of satisfaction in general as follows: assessment for questionnaire expectations of the sample respondents who provide results average score $>5.00$ with the category of calcification is very important for 60 (58.8\%) of respondents means that students judge the questionnaire statement given is very important to be applied. While the assessment for the questionnaire of the reality of the respondent's response gives the result of the average score $>4.00-<4.99$ with the classification category is satisfied by 60 (58.8\%) respondents means that students are satisfied with the financial service STIKes Dharma Husada Bandung.
\end{abstract}

Keywords: Level of Satisfaction, Service 


\section{PENDAHULUAN}

Keadaan persaingan yang cukup kompetitif antar perguruan tinggi menuntut lembaga pendidikan memperhatikan mutu pendidikan dan kelembagaan sehingga mampu serta unggul dalam persaingan tersebut. Perguruan tinggi harus melakukan langkah antisipasi guna menghadapi persaingan yang semakin kompetitif serta bertanggung jawab untuk menggali dan meningkatkan segala aspek pelayanan yang dimiliki, karena sebuah pelayanan yang dimiliki oleh lembaga tertentu akan menjadi gambaran dari kualitas lembaga tersebut, jika pelayanan yang diberikan menurut konsumen itu baik maka sebuah lembaga tersebut bisa dikatakan baik. ${ }^{1}$

Sekolah Tinggi Ilmu Kesehatan Dharma Husada Bandung sebagai lembaga pelayanan pendidikan, terdapat pelimpahan kewenangan pengelolaan pemenuhan jaminan kualitas terhadap mahasiswa tingkat II. Sehingga berdasarkan desentralisasi tersebut, Program studi berkewajiban memenuhi jaminan kualitas. Utamanya yang secara langsung bersinggungan dengan mahasiswa tingkat II antara lain adalah jaminan kualitas pelayanan bagian keuangan.

Kualitas pelayanan bagian keuangan tidak terlepas dari prinsip-prinsip administrasi pelayanan sebagai berikut: prinsip efesiensi adalah prinsip yang berkenaan dengan penggunaan sumber daya yang ada baik meliputi fasilitas, tenaga, hardware dan software, dan resources yang lain untuk mendukung keberhasilan tugas administrasi pelayanan. Selanjutnya prinsip pengelolaan berkenaan dengan prinsip manajemen seperti prinsip planning, organizing, controlling dan directing, kemudian prinsip prioritas yang berkenaan dengan pengutamaan suatu aktivitas apabila terjadi double job dalam satu tempo, semisal munculnya pekerjaan manajemen dan operatif dalam waktu bersamaan. Seringkali seorang administrator mendahulukan tugas operatif, sedangkan melupakan tugas manajemen yang seharusnya menjadi prioritasnya dan prinsip teamwork yaitu kerjasama baik antar orang yang terlibat dalam suatu secara vertikal maupun horisontal tentunya akan menciptakan suatu konduktifitas iklim dan memacu pada keberhasilan suatu teamwork project. ${ }^{1,2,3,4,5}$

Prinsip-prinsip tersebut di atas merupakan bagian penting dalam pengaplikasian administrasi akademik, oleh karena itu ketika prinsip - prinsip itu dipenuhi maka akan mencapai tujuan dibentuknya tujuan dari pelayanan adalah membentuk manajemen yang baik, mendorong produktivitas kerja, memaksimalkan pemanfaatan SDM dan sumber daya lain (uang, material, metode) secara terpadu, sehingga tercapai tujuan yang diharapkan. Hal ini dilakukan untuk upaya memberikan kepuasan kepada mahasiswa.

Kepuasan merupakan perasaan senang ataupun kecewa seseorang yang berasal dari perbandingan antara kesannya terhadap kinerja (atau hasil) suatu produk dan harapan-harapannya. Apabila kinerja lebih kecil dari harapan konsumen akan merasakan tidak puas. Apabila kinerja sama dengan harapan konsumen akan merasakan puas. Apabila kinerja melebihi harapan, konsumen akan merasakan sangat puas. Ketika konsumen merasakan ketidakpuasan, konsumen akan enggan untuk menggunakan lagi jasa perusahaan tadi. Mereka akan cenderung untuk mencari perusahaan lain yang mereka anggap akan menawarkan tingkat kepuasan yang mereka harapkan, atau dengan kata lain jika tingkat kepuasan yang dirasakan rendah, maka akan mempengaruhi niat untuk berpindah. ${ }^{6}$ Penelitian ini bertujuan untuk mengetahui secara umum tingkat kepuasan mahasiswa terhadap pelayanan bagian keuangan yang ada di lingkungan STIKes Dharma Husada Bandung.

\section{METODE PENELITIAN}

Dalam penelitian ini jenis penelitian yang digunakan adalah riset deskriptif sesuai dengan tujuan penelitian untuk menguraikan sifat-sifat dari suatu keadaan. Data yang diperlukan akan diperoleh berdasarkan rumusan masalah. "Metode deskriptif kuantitatif dipergunakan untuk pencarian fakta dengan interpretasi yang tepat dan tujuannya adalah untuk mencari gambaran yang sistematis, fakta yang akurat". 7 Sesuai dengan apa yang menjadi tujuan penelitian ini, riset deskriptif ini dilakukan untuk menguraikan sifat-sifat dari suatu keadaan yakni untuk mengetahui seberapa tinggi kepuasan Mahasiswa tingkat II terhadap pelayanan bagian keuangan STIKes Dharma Husada Bandung di tinjau dari pelayanan yang dialami dengan pelayanan yang diharapkan 
sesuai dengan indikator kualitas layanan yaitu Reliability (kepercayaan), Responsiveness (daya tanggap), Assurance (keyakinan), Emphaty (perhatian individu), dan Tangibles (berwujud).

Metode dalam pengambilan sampel dalam penelitian ini menggunakan stratifield random sampling yaitu pengambilan sampel dengan memperhatikan strata (tingkatan) didalam populasi. ${ }^{8,9}$ Data yang didapat dari pengukuran tingkat kepuasan mahasiswa terhadap pelayanan bagian keuangan kemudian diolah menggunakan teknik deskriptif dimana hasil yang didapatkan menggambarkan tingkat kepuasan mahasiswa. tingkat II.

Pelaksanaan survei kepuasan mahasiswa tingkat II terhadap penyelenggaraan pelayanan mahasiswa tingkat II dapat dilaksanakan melalui tahapan perencanaan, persiapan, pelaksanaan, pengolahan dan penyajian hasil survei, yang mencakup langkah-langkah, sebagai berikut: menyusun instrumen survei, menentukan besaran dan teknik penarikan sampel, menentukan responden, melaksanakan survei, mengolah hasil survei dan menyajikan dan melaporkan hasil. Untuk melakukan survei dapat menggunakan teknik survei, antara lain: kuesioner dengan wawancara tatap muka, kuesioner melalui pengisian sendiri dan kuesioner elektronik (internet/esurvey).

Instrument pengukuran tingkat kepuasan mahasiswa tingkat II terhadap pelayanan bagian keuangan adalah Instrument kepuasan mahasiswa tingkat II terhadap pelayanan bagian keuangan terdiri dari 20 pernyataan. Nilai pernyataan dalam instrument kuesioner ini terdiri atas 2, yaitu penyataan harapan dan kenyataan.

Dalam setiap pernyataan dalam kuisioner ini mempunyai skala 1-5. Untuk pernyataan yang bersifat harapan mempunyai Nilai skala 1 adalah nilai terendah dalam rentang nilai 1 harapan yang ada, artinya responden menilai pernyataan tersebut sangat tidak penting terhadap pernyataan yang diberikan didalam kuesioner tersebut. Nilai skala 2 adalah tidak penting, artinya responden menganggap tidak penting terhadap pernyataan yang diberikan didalam kuesioner tersebut. Nilai skala 3 adalah ragu - ragu, artinya responden ragu - ragu dalam menilai pernyataan yang diberikan didalam kuesioner tersebut. Ninai skala 4 adalah penting, artinya responden menggap penting dengan pernyataan yang di sajikan dalam kuisioner tersebut. Sedangkan nilai tertinggi adalah skala 5 dengan penilaian sangat penting, artinya responden menganggap sangat penting terhadap pernyataan yang di sajikan dalam pernyataan dalam kuisiner kepuasan mahasiswa tingkat II STIKes Dharma Husada Bandung terhadap pelayanan bagian keuangan STIKes Dharma Husada Bandung.

Untuk penilaian pernyataan kenyataan mempunyai skala 1-5 dimana skala terendah adalah 1 dengan pernyataan kepuasan tidak puas, yang artinya responden menganggap tidak puas dengan pernyataan yang disajikan dalam kuisioner. Nilai skala 2 adalah kurang puas, artinya responden menganggap kurang puas dengan pernyataan yang disajikan dalam kuisioner. Nilai skala 3 adalah cukup puas, artinya responden menilai cukup puas dengan pernyataan yang diberikan dalam kuisioner. Nilai skala 4 adalah puas, artinya responden menilai puas dengan pernyataan yang diberikan dalam kuisioner. Dan nilai skala tertinggi dalam kuisioner ini adalah 5 dengan penilaian sangat puas, artinya responden menilai sangat puas dengan pernyataan yang diberikan dalam kuisioner.

Proses pengolahan data dilakukan dengan program SPSS. Selanjutnya melakukan penyusunan tabel klasifikasi untuk menentukan nilai rata-rata kepuasan tiap aspek yang didapatkan, sehingga dapat disimpulkan tingkat kepuasan mahasiswatingkat II terhadap aspek yang dinilai. Berdasarkan nilai rata-rata tersebut dapat disusun tabel klasifikasi skala kepuasan mahasiswatingkat II terhadap pelayanan bagian keuangan terhadap mahasiswatingkat II STIKes Dharma Husada Bandung. Adapun tabelnya adalah sebagai berikut:

Tabel 1.Klasifikasi Skala Kepuasan Mahasiswa Tingkat II Terhadap Pelayanan Bagian Keuangan STIKes Dharma Husada Bandung

\begin{tabular}{ll}
\hline Rata - rata Skor Jawaban & Klasifikasi Kepuasan \\
\hline$>5,00$ & Sangat Puas/Sangat Penting \\
\hline
\end{tabular}




\begin{tabular}{ll}
\hline$>4,00-4,99$ & Puas/Penting \\
$>3,00-3,99$ & Cukup Puas/Ragu - ragu \\
$>2,00-2,99$ & Kurang Puas/Tidak Penting \\
$>1,00-1,99$ & Tidak Puas/Sangat Tidak Penting ${ }^{10}$ \\
\hline
\end{tabular}

\section{HASIL PENELITIAN}

Hasil Pengukuran Statistik Pernyataan Harapan

Tabel 2. Hasil Penghitungan Pernyataan Harapan

\begin{tabular}{lll}
\hline Kategori & Frekuensi & Persentase \\
\hline Ragu-ragu & 12 & 11,8 \\
Penting & 30 & 29,4 \\
Sangat penting & 60 & 58,8 \\
\hline Total & 102 & 100,0 \\
\hline
\end{tabular}

Tabel 1 menunjukkan bahwa persentase terbesar responden menjawab sangat penting terhadap kenyataan yaitu $60(58,8 \%)$.

\section{Hasil Pengukuran Statistik Pernyataan Kenyataan}

Tabel 3. Hasil Penghitungan Pernyataan Kenyataan

\begin{tabular}{lll}
\hline Kategori & Frekuensi & Persentase \\
\hline Kurang puas & 10 & 9,8 \\
Cukup puas & 12 & 11,8 \\
Puas & 60 & 58,8 \\
Sangat Puas & 20 & 19,6 \\
\hline Total & 102 & 100 \\
\hline
\end{tabular}

Tabel 3 menunjukkan bahwa persentase terbesar responden menjawab puas terhadap pelayanan bagian keuangan STIKes Dharma Husada yaitu 60 reponden $(58,8 \%)$.

Dari 102 responden yang telah mengisi kuesioner kepuasan mahasiswa tingkat II terhadap pelayanan, hasil rata-rata menunjukan hasil 60 (58,8\%) responden menyatakan puas pada pernyataan yang disajikan dalam kuisioner. Sebanyak $20(19,6 \%)$ responden menyatakan sangat puas pada pernyataan yang disajikan dalam kuesioner. Sebanyak $12(11,8 \%)$ responden menyatakan cukup puas pada pernyataan yang disajikan dalam kuisioner. Dan dari 102 mahasiswa tingkat II yang menjadi responden sebanyak $10(9,8 \%)$ responden menyatakan kurang puas terhadap pernyataan yang disajikan dalam kuesioner kepuasan mahasiswa tingkat II terhadap pelayanan bagian keuangan STIKes Dharma Husada Bandung.

Ternyata menurut kenyataan bahwa kepuasan mahasiswa dibawah harapan. Kepuasan merupakan perasaan senang ataupun kecewa seseorang yang berasal dari perbandingan antara kesannya terhadap kinerja (atau hasil) suatu produk dan harapan-harapannya. Apabila kinerja lebih kecil dari harapan konsumen akan merasakan tidak puas. Apabila kinerja sama dengan harapan konsumen akan merasakan puas. Apabila kinerja melebihi harapan, konsumen akan merasakan sangat puas. Ketika konsumen merasakan ketidakpuasan, konsumen akan enggan untuk menggunakan lagi jasa perusahaan tadi. Mereka akan cenderung untuk mencari perusahaan lain yang mereka anggap akan menawarkan tingkat kepuasan yang mereka harapkan. Atau dengan kata lain jika tingkat kepuasan yang dirasakan rendah, maka akan mempengaruhi niat untuk berpindah. ${ }^{6}$

Untuk meningkatkan kepuasan mahasiswa terhadap pelayanan bagian keuangan maka disiplin kerja harus lebih ditingkatkan, jadwal pekerjaan, kebersihan serta kerapihan ruangan harus diperhatikan. 


\section{PEMBAHASAN}

\section{Harapan terhadap Pelayanan Bagian Keuangan}

Hasil pengolahan data menggunakan SPSS menunjukkan sebagian besar mahasiswa tingkat II menganggap sangat penting terhadap pernyataan yang disajikan dalam kuesioner kepuasan mahasiswa tingkat II terhadap pelayanan bagian keuangan STIKes Dharma Husada Bandung. Dari 102 responden, sebanyak $60(58,8 \%)$ orang rata-rata menjawab sangat penting terhadap pernyataan yang disajikan dalam kuesioner. Sebanyak $30(29,4 \%)$ responden rata-rata menjawab sangat penting terhadap pernyataan yang di sajikan dalam kuesioner. Dan dari 102 responden, sebanyak 12 $(11,8 \%)$ responden rata - rata menjawab ragu - ragu terhadap pernyataan yang disajikan dalam kuisioner kepuasan mahasiswa tingkat II terhadap pelayanan bagian keuangan STIKes Dharma Husada Bandung.

Hal ini sangat penting ini untuk memperbaiki tingkat pelayanan kepada mahasiswa karena harapan adalah keinginan yang diharapkan mahasiwa agar mendapatkan pelayanan sesuai strandar, harapan dapat tercapai ketika pelayanan keuangan sesuai dengan harapan yaitu prosedur pelayanan di bagian keuangan tidak berbelit-belit, proses pelayanan di bagian Keuangan cepat dan tepat, kegiatan administrasi rapi dan teratur, Staf Keuangan memberi pelayanan yang memuaskan serta disiplin kerja yang tinggi dan penyampaian informasi jelas dan mudah dimengerti.

\section{Kenyataan terhadap Pelayanan Bagian Keuangan}

Dari 102 responden yang telah mengisi kuesioner kepuasan mahasiswa tingkat II terhadap pelayanan, hasil rata-rata menunjukan hasil $60(58,8 \%)$ responden menyatakan puas pada pernyataan yang disajikan dalam kuisioner. Sebanyak $20(19,6 \%)$ responden menyatakan sangat puas pada pernyataan yang disajikan dalam kuesioner. Sebanyak $12(11,8 \%)$ responden menyatakan cukup puas pada pernyataan yang disajikan dalam kuisioner. Dan dari 102 mahasiswa tingkat II yang menjadi responden sebanyak $10(9,8 \%)$ responden menyatakan kurang puas terhadap pernyataan yang disajikan dalam kuesioner kepuasan mahasiswa tingkat II terhadap pelayanan bagian keuangan STIKes Dharma Husada Bandung.

Ternyata menurut kenyataan bahwa kepuasan mahasiswa dibawah harapan. Kepuasan merupakan perasaan senang ataupun kecewa seseorang yang berasal dari perbandingan antara kesannya terhadap kinerja (atau hasil) suatu produk dan harapan-harapannya. Apabila kinerja lebih kecil dari harapan konsumen akan merasakan tidak puas. Apabila kinerja sama dengan harapan konsumen akan merasakan puas. Apabila kinerja melebihi harapan, konsumen akan merasakan sangat puas. Ketika konsumen merasakan ketidakpuasan, konsumen akan enggan untuk menggunakan lagi jasa perusahaan tadi. Mereka akan cenderung untuk mencari perusahaan lain yang mereka anggap akan menawarkan tingkat kepuasan yang mereka harapkan. Atau dengan kata lain jika tingkat kepuasan yang dirasakan rendah, maka akan mempengaruhi niat untuk berpindah. ${ }^{6}$

Untuk meningkatkan kepuasan mahasiswa terhadap pelayanan bagian keuangan maka disiplin kerja harus lebih ditingkatkan, jadwal pekerjaan, kebersihan serta kerapihan ruangan harus diperhatikan.

\section{SIMPULAN}

Tingkat kepuasan pelayanan bagian keuangan di lingkungan kampus STIKes Dharma Husada Bandung, menunjukkan nilai rata-rata kepuasan secara umum untuk kuesioner harapan terhadap sampel responden yang ada memberikan hasil skor rata-rata > 5,00 dengan kategori kalsifikasi adalah sangat penting sebesar $60(58,8 \%)$ responden. Artinya adalah mahasiswa tingkat II menilai pernyataan kuesioner yang diberikan sangat penting untuk diaplikasikan. Sedangkan penilaian untuk kuesioner kenyataan terhadap respon responden memberikan hasil skor rata-rata $>4,00-<$ 4,99 dengan kategori klasisfikasi adalah puas sebesar 60 (58,8\%) responden. Artinya mahasiswa tingkat II merasa puas dengan pelyanan bagian keuangan STIKes Dharma Husada Bandung. 


\section{SARAN}

Meskipun secara umum mahasiswa tingkat II STIKes Dharma Husada Bandung merasa puas terhadap pelayanan bagian keuangan, namun ada beberapa masukan yang harus diperhatikan untuk memaksimalkan pelayanan di bagian keuangan. Adapun beberapa masukan sebagai berikut:

1. Disiplin kerja harus lebih ditingkatkan.

2. Jadwal pekerjaan harus diperhatikan.

3. Kebersihan dan kerapihan ruangan harus diperhatikan.

\section{DAFTAR PUSTAKA}

1. M. daryanto. Administrasi pendidikan. Jakarta: PT Rineka Cipta; 1998

2. Burhanudin, Yusak. Administrasi Pendidikan. Bandung: CV Pustaka Setia; 1998

3. Herabudin. Administrasi dan Supervisi Pendidikan. Bandung: CV Pustaka Setia; 2009

4. Engkoswara dan Aan Komariah. Administrasi pendidikan. Bandung: Alfabeta; 2010

5. Suharsaputra, Uhar. Administrasi Pendidikan. Bandung: PT Refika Aditama; 2013

6. Kotler, Philip. Marketing Management. 11st edition. Prentice Hall, New Jersey; 2003

7. Furchan, A. Pengantar penelitian dalam pendidikan. Yogyakarta: Pustaka Pelajar; 2004

8. Sugiarto, dkk. Teknik Sampling. Jakarta: PT Gramedia Pustaka Utama; 2001

9. Purwanto, J. Editor: Sri Budianti. Dasar-dasar metode penarikan sampel. Jakarta: STIS; 2003

10. Sugiono. Metode Penelitian Kuantitatif, Kualitatif dan R\&D. Bandung: Alfabeta; 2009 